\title{
Selected quality traits of eggs and the productivity of newly created laying hen hybrids dedicated to an extensive rearing system
}

\author{
Justyna Batkowska and Antoni Brodacki \\ Department of Biological Basis of Animal Production, University of Life Sciences in Lublin, \\ 13 Akademicka St., 20-950 Lublin, Poland \\ Correspondence to: Justyna Batkowska (justyna.batkowska@up.lublin.pl)
}

Received: 27 December 2016 - Revised: 7 March 2017 - Accepted: 13 March 2017 - Published: 28 April 2017

\begin{abstract}
The aim of the study was to evaluate the usefulness of hybrids derived from Greenleg Partridge cocks and Rhode Island Red (GPR) hens for an extensive rearing system (RS), with special emphasis on highquality table eggs. Newly created hybrids were compared to Hy-Line Brown (HLB) hens. The experiment was carried out with a total of 2400 hens. Both hybrid types (H's) were divided into two equal groups according to the rearing system: intensive (I) and extensive (E). The traits analysed in hens were body weight at the 8th, 16th, and 33rd weeks of age; laying production; and feed intake. At the 33rd week of a bird's age, egg quality was evaluated. The results of the study showed different reaction of the hybrids to the rearing system. This may confirm better usefulness of GPR for extensive farming and HLB hens for intensive methods of rearing. Furthermore, it can be concluded that the extensive system had a positive impact on the productivity of GPR birds.
\end{abstract}

\section{Introduction}

The quality of table eggs may depend on many factors, such as genotype, age (Zita et al., 2009; Sarica et al., 2012), environmental conditions, feed supplements (Safaa et al. 2008), or rearing system (RS) of hens (Đukić-Stojčić et al., 2009; Batkowska et al., 2014). Due to a higher level of welfare and consumer preferences, the so-called organic, free-range, backyard, and extensive methods of poultry housing have become increasingly popular (Ferrante et al., 2009; Krawczyk, 2009; Tůmová et al., 2009). However, in the market there are still only a few gene sets of laying bird hybrids that would provide satisfactory production results in such kinds of housing systems. Additionally, because of the opinion that typical commercial laying hybrids under extensive housing conditions are not able to fully exploit their genetic potential, the use of local breeds and their hybrids for organic farming is suggested because of their better adaptation to changeable environmental conditions (Rizzi and Chiericato, 2005; Zita et al., 2009).
The aim of this study was to evaluate the usefulness of hybrids derived from Greenleg Partridge cocks and Rhode Island Red hens (GPR) for an extensive RS with special emphasis on obtaining high-quality table eggs.

Greenleg Partridge is the oldest native Polish breed of hen, developed at the end of the 19th century, and due to their occurrence mainly in south-eastern Poland, they were called "Galician hens". The breed was first exhibited with the name of Greenleg at a show in Lviv (Ukraine) in 1894. The breed standard was established in 1923 in Poland. Greenleg Partridge chickens have been maintained in a conservation flock since 1960 (Wójcik et al., 2012). Recently they have not been subjected to selection for productive trait improvement. They are characterized by low body weight (around 1700-1800 g), green legs, and grey, partridge-like plumage. They produce good-tasting eggs $(\approx 56 \mathrm{~g})$ with cream-coloured shells and a high percentage of yolk content (Krawczyk et al., 2011). Greenleg Partridge hens today are progressively used in freerange and organic production systems, and their eggs are marketed at high prices (Krawczyk and Sokołowicz, 2015). The choice of Greenleg Partridge was also dictated by the 
Table 1. Nutritional value of feed in both systems of rearing used up to the 16th week of the laying hens' age.

\begin{tabular}{lrrr}
\hline Rearing system & \multicolumn{2}{c}{ Intensive } & Extensive \\
\cline { 2 - 2 } Age of birds (weeks) & $0-8$ & $9-16$ & $9-16$ \\
Ingredients & & & \\
\hline Dry matter (\%) & 89.0 & 88.0 & 88.1 \\
Metabolic energy (MJ kg ${ }^{-1}$ ) & 12.0 & 12.3 & 12.0 \\
Total protein (g) & 180.0 & 155.0 & 156.0 \\
Crude fat (g) & 30.0 & 28.0 & 23.3 \\
Crude fibre (g) & 40.0 & 48.0 & 57.0 \\
Crude ash (g) & 40.0 & 57.0 & 41.5 \\
Calcium (g) & 8.0 & 9.0 & 6.7 \\
Phosphorus (g) & 5.8 & 6.0 & 6.0 \\
Magnesium (g) & 1.5 & 1.5 & 2.37 \\
Sodium (g) & 0.8 & 1.64 & 1.16 \\
Lysine (g) & 1.1 & 0.75 & 0.76 \\
Methionine (g) & 0.42 & 0.34 & 0.36 \\
\hline
\end{tabular}

fact that in popular opinion hens of this breed are characterized by beneficial traits of eggs, better disease resistance, and high resourcefulness in searching for food. All of these features are important in the extensive rearing of laying hens.

The breed Rhode Island Red was also created in the second half of the 19th century in the state of Rhode Island (USA) by crossing different hen breeds with Asian birds such as Cochins and Malay bantams and through selection for increased egg production. The Rhode Island Red (R-11) line was imported into Poland from Great Britain before 1939. As a dual-purpose type, by the mid-1970s it accounted for $50 \%$ of the population of commercial farms and backyard flocks. The birds are characterized by yellow skin and good dressing percentage. Due to its genetically determined resistance to Marek's disease, the breed is especially suitable for backyard free-range farming (Połtowicz et al., 2004; Mohammed et al., 2013).

Newly created hybrids were compared to Hy-Line Brown (HLB) hens, which are currently the leading commercial hybrids in Poland, regardless of housing system.

\section{Materials and methods}

The research material consisted of 2400 laying hens: Greenleg Partridge and Rode Island Red hybrids (GPR) and HyLine Brown (HLB). Birds of both hybrid types (H's) were divided into two equal groups (four replications each containing 150 layer hens) according to the RS - intensive (I) and extensive (E). Up to the eighth week of age, the birds were maintained on deep litter. After this time the birds from E groups were transferred to special sheds with green runs and reared at stock density of 6 hens $\mathrm{m}^{-2}$ of hen house (on the run: $1 \mathrm{hen} / 4 \mathrm{~m}^{2}$ ). The natural length of daylight was used (ca. 16h). Microclimate parameters were not controlled in
Table 2. Nutritional value of feed in both systems of rearing used after the 16th week of the laying hens' age.

\begin{tabular}{lrr}
\hline & \multicolumn{2}{c}{ Rearing system } \\
\cline { 2 - 3 } Ingredients & Intensive & Extensive \\
\hline Dry matter (\%) & 87.7 & 87.4 \\
Metabolic energy (MJ) & 11.51 & 11.63 \\
Total protein (\%) & 17.99 & 15.45 \\
Crude fat (\%) & 3.80 & 2.98 \\
Crude fibre (\%) & 3.90 & 3.88 \\
Crude ash (\%) & 4.92 & 3.78 \\
\hline
\end{tabular}

this system. The so-called intensive groups were maintained on deep litter throughout the whole rearing period, at stock density of 9 hens $\mathrm{m}^{-2}$, under regulated environmental parameters: temperature $\left(21^{\circ} \mathrm{C}\right)$, humidity $(40-60 \%)$, and lighting program (16h of light, $5 \mathrm{~lx})$.

The nutritional value of the feed used for birds in both housing systems up to the 16th week of age is shown in Table 1 . From the 9 th to the 16 th weeks of rearing the hens kept extensively received additionally green fodder in the amount of $20 \mathrm{~g} / \mathrm{bird} /$ day. From the 17 th week of age the hens from E groups were given fodder in the following proportions: $60 \%$ of balanced mixture (composed of wheat $-40 \%$, corn $30 \%$, wheat bran $-10 \%$, soya meal $-21 \%$, limestone $-8 \%$, and premix $-1 \%$ ), $30 \%$ of crushed wheat, $10 \%$ of wheat bran, and $5 \%$ of green forage of alfalfa, calculated on the basis of dry matter. Nutritional composition of green fodder was as follows (per $1000 \mathrm{~g}$ ): dry matter $186.4 \mathrm{~g}$, metabolic energy $259.6 \mathrm{kcal} / 1.09 \mathrm{MJ}$, crude protein $42.8 \mathrm{~g}$, crude fat $7.2 \mathrm{~g}$, crude fibre $40.5 \mathrm{~g}$, and crude ash $23.4 \mathrm{~g}$. The chemical composition of other feed is presented in Table 2. Feed was analysed according to procedures carrying out by National Laboratory of Feedingstuffs (National Research Institute of Animal Production, Balice near Kraków, Poland).

The following productivity traits were analysed in hens: body weight at the 8 th, 16 th, and 33 rd weeks of age ( 50 birds per group were weighted individually), as well as the number of eggs, laying production percentage, and feed intake per 1 egg and per 1 hen day $^{-1}$. At the 33rd week of the birds' age, the evaluation of egg quality was performed. For this purpose, 60 eggs were collected from each replication group for 3 consecutive days. All eggs were collected at the same time (in the morning) from all groups. They were chosen randomly and evaluated on the same day. The following traits were evaluated: shape index, egg weight, and specific gravity (calculated on the basis of Archimedes principle), features describing the shell (colour, strength, weight, thickness, and density), albumen (weight, height, Haugh units), and yolk (colour, weight). Proportions of particular elements of eggs were calculated as well. The evaluation of the egg traits was performed using electronic-set egg quality measurements $\left(\mathrm{TSS}^{\circledR}\right)$ and an Instron Mini 55 device. 
Table 3. Effect of the hybrid type $(\mathrm{H})$, rearing system $(\mathrm{RS})$, and their interaction $(\mathrm{H} \times \mathrm{RS})$ on the productivity traits in laying hens (values presented as means).

\begin{tabular}{|c|c|c|c|c|c|c|c|c|}
\hline \multirow{2}{*}{$\begin{array}{l}\text { Rearing system (RS) } \\
\text { Hybrid }(\mathrm{H}) \\
\text { Trait }\end{array}$} & \multicolumn{2}{|c|}{ E } & \multicolumn{2}{|c|}{ I } & \multirow[t]{2}{*}{ SEM } & \multicolumn{3}{|c|}{ Probability } \\
\hline & GPR & HLB & GPR & HLB & & $\mathrm{H}$ & RS & $\mathrm{H} \times \mathrm{RS}$ \\
\hline Body weight at 8th week of life & - & - & $646.2^{\mathrm{a}}$ & $720.0^{b}$ & 6.643 & 0.006 & - & - \\
\hline Body weight at 16 th week of life & $1710^{\mathrm{b}}$ & $1396^{\mathrm{a}}$ & $1733^{\mathrm{b}}$ & $1375^{\mathrm{a}}$ & 17.70 & 0.008 & 0.695 & 0.241 \\
\hline Body weight at 33 rd week of life & 1872 & 1778 & 1899 & 1920 & 17.26 & 0.458 & 0.255 & 0.785 \\
\hline Average laying production $(\%)$ & $79.8^{\mathrm{b}}$ & $80.4^{\mathrm{b}}$ & $72.9^{\mathrm{a}}$ & $84.7^{\mathrm{c}}$ & 0.842 & 0.000 & 0.340 & 0.000 \\
\hline Average feed conversion per 1 egg $(\mathrm{g})$ & $141.8^{\mathrm{a}}$ & $148.4^{\mathrm{a}}$ & $162.1^{\mathrm{b}}$ & $147.8^{\mathrm{a}}$ & 1.673 & 0.182 & 0.001 & 0.000 \\
\hline Average feed conversion per 1 hen day ${ }^{-1}(\mathrm{~g})$ & $113.0^{\mathrm{a}}$ & $116.3^{\mathrm{b}}$ & $116.5^{\mathrm{b}}$ & $109.6^{\mathrm{a}}$ & 4.912 & 0.160 & 0.202 & 0.001 \\
\hline
\end{tabular}

RS is rearing system. E is extensive. I is intensive. $\mathrm{H} \times \mathrm{RS}$ is the interaction effect of hybrid type and rearing system. GPR is the newly created hybrid Greenleg Partridge $\times$ Rhode Island Red. HLB is the commercial hybrid Hy-Line Brown. ${ }^{a}, b, c$, $d$ show values that are significantly different.

During the whole experiment principles of ethics and the welfare of the birds were maintained. Experimental procedures were approved by the III Local Ethics Committee for Experiments on Animals in Warsaw (approval no. 27/2009 of 16 April 2009). The data collected were analysed using the statistical package SPSS V21.0 (IBM, 2011). The normality of data was verified using the Kolmogorov-Smirnov test. Further two-way ANOVA was applied to assess the effect of the RS, $\mathrm{H}$, and their interaction on the productivity and egg traits in the hens. Survivability of birds was statistically evaluated by a nonparametric $\chi^{2}$ test.

\section{Results}

During the trial, 33 cases of death in birds were registered and the survivability in the groups was calculated as follows: 98.7 and $99.0 \%$ in GPR E and GPR I and 98.3 and $98.5 \%$ in HLB E and HLB I respectively. The dependence of this parameter on experimental groups was not statistically confirmed $\left(\chi^{2} P=0.790\right)$. This showed that uncontrolled and non-optimal environmental conditions of the extensive RS did not result in deterioration of the birds' health status regardless of hybrid type.

Table 3 shows the effect of the RS, H, and their interaction on the growth performance of the laying hens. Considerably higher body weight (approximately $10 \%$ ) at 8 weeks of age was displayed in HLB in comparison to GPR pullets. At 16 weeks of life these relations were reversed and higher body weight was achieved by GPR birds, regardless of the housing system $(P \leq 0.008)$. The body weight of birds at the 33 rd week of age was almost equal in all groups. There was no interaction between the experimental factors in regard to the body weight of the hens.

The average laying percentage ranged from 72 to $84 \%$ and depended on the genotype and housing system of the birds. Birds from the different genotypes responded differently to extensive maintenance conditions $(P \leq 0.000)$. GPR hybrids from the $E$ group demonstrated a significantly higher value of

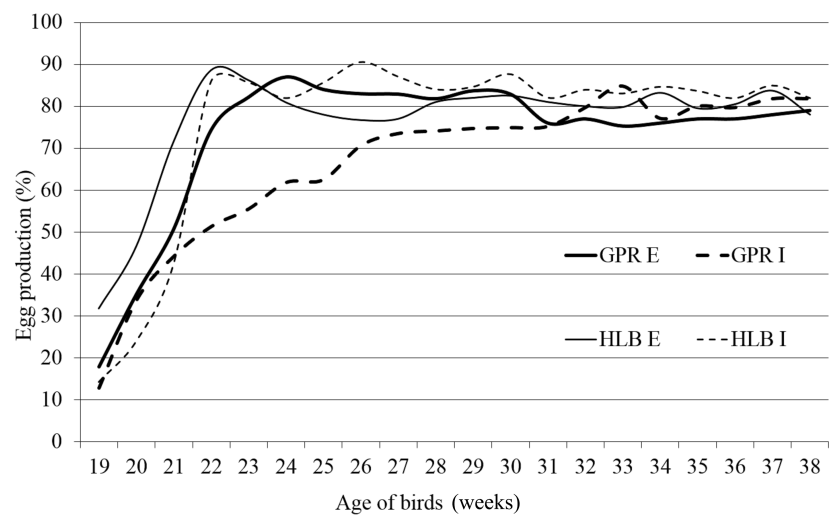

Figure 1. Laying curves of hens according to the hybrid type and rearing system ( $\mathrm{E}$ is the extensive system of rearing, $\mathrm{I}$ is the intensive system of rearing, GPR is the newly created hybrid Greenleg Partridge $\times$ Rhode Island Red, and HLB is the commercial hybrid Hy-Line Brown).

egg production than birds in the I group, while in HLB hens, opposite relations were recorded. This could result from difficulties in adaptation to a closed housing system in GPR hybrids.

The average feed conversion per 1 egg (Table 3 ) was the lowest in GPR hens kept extensively and HLB birds maintained intensively. The value of this parameter indicates that the GPR hens are most suitable to keep under extensive conditions. HLB layers in both intensive and extensive RSs consumed a similar amount of feed per egg ( $148 \mathrm{~g})$. Similar patterns were recorded for feed conversion per 1 bird day $^{-1}$. The lowest values of this indicator were noticed in GPR $E$ and HLB I hens. Both parameters connected with feed conversion remained under the interactional influence of both experimental factors.

Figure 1 illustrates laying curves of hens depending on $\mathrm{H}$ and RS. The achieved body weight did not have a big impact on sexual maturity of birds; regardless of the group, first 
Table 4. Effect of the hybrid type $(\mathrm{H})$, rearing system $(\mathrm{RS})$, and their interaction $(\mathrm{H} \times \mathrm{RS})$ on the external traits and proportions of egg elements.

\begin{tabular}{|c|c|c|c|c|c|c|c|c|}
\hline \multirow{2}{*}{$\begin{array}{l}\text { Rearing system }(\mathrm{RS}) \\
\text { Hybrid }(\mathrm{H}) \\
\text { Trait }\end{array}$} & \multicolumn{2}{|c|}{$\mathrm{E}$} & \multicolumn{2}{|c|}{ I } & \multirow[t]{2}{*}{ SEM } & \multicolumn{3}{|c|}{ Probability } \\
\hline & GPR & HLB & GPR & HLB & & $\mathrm{H}$ & $\mathrm{RS}$ & $\mathrm{H} \times \mathrm{RS}$ \\
\hline Egg weight $(g)$ & $53.7^{\mathrm{b}}$ & $59.0^{\mathrm{d}}$ & $50.8^{\mathrm{c}}$ & $60.6^{\mathrm{a}}$ & 0.196 & 0.000 & 0.090 & 0.000 \\
\hline Egg specific gravity $\left(\mathrm{g} \mathrm{cm}^{-3}\right)$ & $1.088^{\mathrm{a}}$ & $1.083^{\mathrm{b}}$ & $1.082^{\mathrm{b}}$ & $1.089^{\mathrm{a}}$ & 0.000 & 0.000 & 0.874 & 0.000 \\
\hline Shape index (width to length, \%) & $75.4^{\mathrm{a}}$ & $77.6^{\mathrm{b}}$ & $77.1^{\mathrm{b}}$ & $75.1^{\mathrm{a}}$ & 0.278 & 0.030 & 0.168 & 0.000 \\
\hline Proportions yolk & $29.2^{\mathrm{c}}$ & $24.0^{\mathrm{b}}$ & $23.0^{\mathrm{a}}$ & $28.8^{\mathrm{c}}$ & 0.135 & 0.000 & 0.000 & 0.000 \\
\hline albumen & $58.6^{\mathrm{a}}$ & $62.6^{\mathrm{c}}$ & $63.8^{\mathrm{d}}$ & $59.5^{\mathrm{b}}$ & 0.140 & 0.000 & 0.000 & 0.000 \\
\hline shell & $13.1^{\mathrm{b}}$ & $13.4^{\mathrm{b}}$ & $13.2^{\mathrm{a}}$ & $11.6^{\mathrm{a}}$ & 0.085 & 0.000 & 0.003 & 0.000 \\
\hline
\end{tabular}

$\mathrm{RS}$ is rearing system. E is extensive. I is intensive. $\mathrm{H} \times \mathrm{RS}$ is the interaction effect of hybrid type and rearing system. GPR is the newly created hybrid Greenleg Partridge $\times$ Rhode Island Red. HLB is the commercial hybrid Hy-Line Brown. ${ }^{a}, b, c, d$ show values that are significantly different.

eggs appeared in approximately the 19th week of the layers' life. HLB E layers achieved $50 \%$ egg production earliest, between the 20th and 21st weeks, followed by GPR E, GPR I, and HLB I. This could result from a longer lighting day, which was used for the groups kept extensively. HLB E layers also reached the peak production earliest; their productivity amounted to $90 \%$ in the 22 nd and 23rd weeks of rearing. In GPR hybrids the peak production was noticed slightly later, between the 24th and 25th weeks, but their further egg production did not differ from that recorded for commercial laying hybrids. The worst production results were recorded in GPR hens kept intensively, which can confirm poor adaptation of these birds for closed farming.

Table 4 shows the parameters characterizing the external features and proportions of particular morphological elements of eggs obtained from each group of birds as affected by the RS, genotype, and their interaction. The heaviest eggs were obtained from commercial HLB I laying hens $(60.6 \mathrm{~g})$ and the lightest ones from GPR hens kept under intensive housing conditions ( $50.8 \mathrm{~g}$ ). Similarly, the highest egg specific gravity was recorded in eggs from HLB I hens and the lowest from GPR I; the difference amounted to more than $5 \%$. Both egg weight and egg density were influenced by both experimental factors. On the basis of the proportion of long and short egg axis, the egg shape index was calculated. In intensive breeding, eggs from GPR hens were significantly more elongated, while in extensive breeding, eggs from HLB were more elongated. Both types of hybrids showed a diversity of shape, depending on the RS.

The percentage of particular morphological egg elements in the extensive RS varied, depending on the H. The biggest proportion of egg content $(88.3 \%)$ and the smallest of shell $(11.6 \%)$ were observed in the eggs from HLB I birds. It should be emphasized that the GPR E hybrids obtained a substantially higher percentage of yolk $(29.2 \%)$ than other groups of layers. GPR E hybrids also had the biggest yolk content, $0.4-6.2 \%$ in absolute values. The difference was higher by $21.2 \%$, in relative values, than in eggs from the same hybrids kept intensively. In HLB layers these differences were slightly lower and amounted to 4.8 (in absolute values) and $16.6 \%$ in relative values, but in favour of group I birds. For a proportion of all morphological elements of eggs, interaction of experimental factors was significant $(P \leq 0.000)$.

Table 5 presents the characteristics of particular egg elements: yolk, albumen, and shell, depending on $\mathrm{H}$ and their RS. The farming system did not induce significant differences in the yolk weight within commercial HLB hybrids. GPR layers dominated in the extensive system in terms of this parameter. The yolks from GPR E hens were considerably darker in the intensive system. They were also darker than yolks in eggs from HLB birds, regardless of the RS. This could result from using Greenleg Partridge cocks in creating these hybrids. Hens of this breed are very resourceful in finding food, and darker colour of yolk may be the result of intensive foraging and thus consuming more carotenoids from green fodder and plants available on the fowl run. Hybrids from GPR E were characterized by a lower albumen weight than commercial HLB layers. The greater average height of albumen was observed in HLB eggs, probably due to higher albumen content. Eggs from extensively reared birds also showed the highest number of Haugh units (86.7), which may indirectly be indicative of albumen quality. Generally, both the housing system and $\mathrm{H}$ considerably modified the parameters of egg albumen. The significance of the experiment factor interaction was also demonstrated in all the analysed characteristics of egg shell. The smallest shell weight was found in eggs from HLB I hybrids $(6.03 \mathrm{~g})$. It was significantly lower $(34 \%)$ than in eggs from hybrids held extensively and in eggs from GPR hens $(P \leq 0.000)$.

The eggs from GPR E hens were characterized by the highest percentage of reflected light, i.e. they had substantially lighter shell colour $(51.82 \%)$ than in other groups. The shell strength of eggs was similar $(43 \mathrm{~N})$ and it was not influenced by the RS. In the case of HLB layers, group I eggs required significantly greater force to crush the shell $(49.4 \mathrm{~N})$, 
Table 5. Effect of the hybrid type $(\mathrm{H})$, rearing system $(\mathrm{RS})$, and their interaction $(\mathrm{H} \times \mathrm{RS})$ on the internal traits of egg elements.

\begin{tabular}{|c|c|c|c|c|c|c|c|c|c|}
\hline \multirow{2}{*}{\multicolumn{2}{|c|}{$\begin{array}{l}\text { Rearing system }(\mathrm{RS}) \\
\text { Hybrid }(\mathrm{H}) \\
\text { Trait }\end{array}$}} & \multicolumn{2}{|c|}{$\mathrm{E}$} & \multicolumn{2}{|c|}{ I } & \multirow[t]{2}{*}{ SEM } & \multicolumn{3}{|c|}{ Probability } \\
\hline & & GPR & HLB & GPR & HLB & & $\mathrm{H}$ & $\mathrm{RS}$ & $\mathrm{H} \times \mathrm{RS}$ \\
\hline \multirow{2}{*}{$\stackrel{\mathscr{0}}{\stackrel{2}{\circ}}$} & weight (g) & $15.32^{\mathrm{c}}$ & $14.52^{\mathrm{b}}$ & $13.78^{\mathrm{a}}$ & $14.90^{\mathrm{b}}$ & 0.058 & 0.000 & 0.000 & 0.000 \\
\hline & colour (pts) & $9.31^{\mathrm{c}}$ & $8.56^{\mathrm{b}}$ & $8.00^{\mathrm{a}}$ & $8.55^{\mathrm{b}}$ & 0.037 & 0.000 & 0.000 & 0.000 \\
\hline \multirow{3}{*}{ 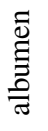 } & weight (g) & $30.79^{\mathrm{a}}$ & $38.05^{\mathrm{b}}$ & $38.32^{\mathrm{b}}$ & $30.86^{\mathrm{a}}$ & 0.164 & 0.000 & 0.587 & 0.000 \\
\hline & height (mm) & $5.52^{\mathrm{a}}$ & $7.64^{\mathrm{c}}$ & $6.89^{\mathrm{b}}$ & $5.47^{\mathrm{a}}$ & 0.058 & 0.000 & 0.001 & 0.000 \\
\hline & Haugh units & $76.14^{\mathrm{a}}$ & $86.71^{\mathrm{c}}$ & $80.59^{\mathrm{b}}$ & $74.50^{\mathrm{a}}$ & 0.379 & 0.000 & 0.000 & 0.000 \\
\hline \multirow{5}{*}{$\begin{array}{l}\overline{\bar{d}} \\
\bar{w}\end{array}$} & strength $(\mathrm{N})$ & $43.45^{\mathrm{a}}$ & $46.32^{\mathrm{b}}$ & $43.75^{\mathrm{a}}$ & $44.38^{\mathrm{a}}$ & 0.326 & 0.003 & 0.279 & 0.138 \\
\hline & colour $(\%)$ & $51.82^{\mathrm{d}}$ & $29.26^{\mathrm{a}}$ & $31.99^{\mathrm{b}}$ & $49.40^{\mathrm{c}}$ & 0.409 & 0.000 & 0.799 & 0.132 \\
\hline & weight (g) & $6.37^{\mathrm{b}}$ & $8.09^{c}$ & $7.90^{\mathrm{b}, \mathrm{c}}$ & $6.03^{\mathrm{a}}$ & 0.061 & 0.000 & 0.000 & 0.000 \\
\hline & thickness (mm) & $0.284^{\mathrm{a}}$ & $0.319^{\mathrm{c}}$ & $0.331^{\mathrm{d}}$ & $0.316^{\mathrm{b}}$ & 0.002 & 0.000 & 0.001 & 0.000 \\
\hline & density $\left(\mathrm{g} \mathrm{cm}^{-3}\right)$ & $97.8^{\mathrm{c}}$ & $112.4^{\mathrm{b}, \mathrm{c}}$ & $110.6^{\mathrm{b}, \mathrm{c}}$ & $93.5^{\mathrm{a}}$ & 0.751 & 0.000 & 0.000 & 0.000 \\
\hline
\end{tabular}

$\mathrm{RS}$ is rearing system. $\mathrm{E}$ is extensive. I is intensive. $\mathrm{H} \times \mathrm{RS}$ is the interaction effect of hybrid type and rearing system. GPR is the newly created hybrid Greenleg Partridge $\times$ Rhode Island Red. HLB is the commercial hybrids Hy-Line Brown. ${ }^{a}$, b, c, d show values that are significantly different.

which was not confirmed in the thickness or density of shell; therefore, it may result from a more spherical shape of the eggs in comparison to the eggs from the other groups. The thickest shell was noticed in eggs laid by GPR I hens. The eggs from the laying hybrids reared under extensive housing conditions were characterized by a greater density than those from hens kept intensively.

\section{Discussion}

The observations concerning body weight of layers (especially in HLB hens) made in this study were opposed to those reported by Küçükyılmaz et al. (2012), who showed that birds from an extensive RS were slightly heavier than birds reared conventionally, while this parameter depended more on the genotype than the RS. However, in the studies of Singh et al. (2009), the birds kept less intensively were characterized by higher body weight. Also, the main cause of variation was the origin of hens. Miao et al. (2005) noticed that layers from open housing were lighter than those from intensive housing because of higher energy output associated with motor activity of birds kept with green run access.

When comparing the productivity of birds in two different housing systems, contradictory opinions can be found in the available references. Lukanov and Alexieva (2013) and Arbona et al. (2009) concluded that egg production is greater in an intensive RS in comparison to an extensive one. Şekeroğlu et al. (2010) stated that hens kept intensively reached sexual maturity 2 days earlier than birds in environmentally friendly farming. The observations made in this study are completely different and more compatible with those presented by Gerzilov et al. (2012). Despite the fact that conventionally reared hens finished the maturation process about
2 weeks earlier than the birds maintained extensively, they reached the period of maximum production more or less at the same time (23 weeks), regardless of the housing system. The egg production in an intensive system between 30 and 33 weeks of age was significantly lower than in extensive rearing and evened out in the following weeks. Birds kept extensively, regardless of the hybrid type, started to lay eggs earlier than I groups; therefore, the length of lighting day, different in these two RSs, seems to be fundamentally important in this case.

Similar to Tauson et al. (1999), in our study the different reaction of various hybrids to the maintenance of system intensity was observed in the case of production parameters. These authors also noticed an increase in egg numbers and laying production (\%), as well as better feed intake and conversion, with increased rearing intensity. Englmaierová et al. (2014) found that the daily feed consumption and feed conversion ratio increased in aviary or litter systems in comparison with cages. Also, hen egg production per day was better in an intensive system than in alternative systems. According to Luiting (1990), the RS does not influence feed intake and the differences probably result from genetics, physical activity and condition, metabolic rate, and temperature. However, the above-mentioned factors might be due to the housing system.

Our results differ from the study of Golden et al. (2012), who found no effect of housing system on egg weight. Krawczyk (2009) indicated a $1.3 \%$ difference in favour of extensive farming, but it was not statistically confirmed. In the research of Singh et al. (2009), the difference in favour of the floor system, in relation to hens kept in cages, amounted to more than $7 \%$. Similar results were reported by Pištěková et al. (2006), analysing hens in litter and cage RSs. Egg 
weight increased with the age of birds during the 9 months of the experiment in almost all terms of analysis (except the first and last month of rearing); considerably bigger eggs were laid by hens kept on the litter.

A statistically significant effect of RS on egg weight, egg shell, and albumen weight was shown by Farrante et al. (2009). The eggs from Hy-Line Brown hens kept on litter were characterized by a higher weight, heavier shell, and higher albumen content than eggs from hens raised in an organic system. Đukić-Stojčić et al. (2012) also evaluated the impact of various cage types on laying hens and the $\mathrm{H}$ on egg quality. They did not show any statistically significant interactions between the analysed experimental factors. However, genotype of birds considerably modified the number of eggs, shell strength, albumen height, and Haugh units. The types of cage also affected the number of eggs, shell thickness, and colour of yolk.

Comparing the impact of various RSs on egg quality parameters, Ahammed et al. (2014) noted the best technological characteristics of albumen in eggs from cages, which is the most intensive maintenance system for laying hens. However, the strongest shell and the best-stained yolk characterized eggs from hens kept in an aviary system. Roll et al. (2009) demonstrated changes in egg quality traits under the influence of RS in the case of yolk colour and shell characteristics, such as thickness, density, and mass, but they were statistically significant only in the period from the 60th to 78th weeks of the hens' lives. Eggs from hens kept in a floor system had a darker colour of yolk and characteristics of shell were better than in the eggs from hens kept in cages. Also, in a paper of Şekeroğlu et al. (2008), the effect of the free-range system was manifested only in darker stained yolks compared to eggs from the litter system.

According to Lewko and Gornowicz (2011), eggs from free-range rearing are characterized by the heaviest and thickest shell, while the shell was lightest and thinnest from the litter. Özbey and Esen (2007) did not confirm any differences in the shell thickness in eggs from the litter and cage systems; however, they showed that the mass of shell was significantly bigger in eggs from cages. Comparing the parameters of egg shell from layers kept under free-range and cage conditions, van den Brandt et al. (2004) and Đukić-Stojčić et al. (2009) did not find any differences between the systems in weight and thickness of shells. In the present study, the impact of housing system on the shell characteristics was clearly visible and statistically significant.

\section{Conclusions}

The results clearly show a completely different reaction of both types of laying hybrids to the applied extensive and intensive RSs. Most of the parameters that were decreased in the birds created by crossing Greenleg Partridge cocks and Rhode Island Red hens showed an increase in Hy-Line
Brown hens and vice versa. This may confirm more usefulness of GPR birds for extensive farming and HLB hens for intensive methods of rearing.

The results of the study showed that the newly created hybrid Greenleg Partridge $\times$ Rhode Island Red is suitable for rearing under an extensive system. This was evidenced by such characteristics as maturity age, the average percentage of egg production, feed conversion per $1 \mathrm{egg}$, and the quality of egg traits. Based on the assessed traits, it can be concluded that the extensive RS positively influenced the birds and their production characteristics. We recommend using Greenleg Partridge $\times$ Rhode Island Red crosses for this system as a source of good-quality table eggs.

Data availability. The original data are available upon request from the corresponding author.

Competing interests. The authors declare that they have no conflict of interest.

Acknowledgements. Research was realized within the project "BIOŻYWNOŚĆ - innowacyjne, funkcjonalne produkty pochodzenia zwierzęcego" (BIOFOOD - innovative, functional products of animal origin) no. POIG.01.01.02-014-090/09 co-financed by the European Union from the European Regional Development Fund within the Innovative Economy Operational Programme 2007-2013.

Edited by: M. Mielenz

Reviewed by: T. Popova and one anonymous referee

\section{References}

Ahammed, M., Chae, B. J., Lohakare, J., Keohavong, B., Lee, M. H., Lee, S. J., Kim, D. M., Lee, J. Y., and Ohh, S. J: Comparison of aviary, barn and conventional cage raising of chickens on laying performance and egg quality, Asian Australas, J. Anim. Sci., 27, 1196-1203, 2014.

Arbona, D. V., Hoffman, J. B., and Anderson, K. E.: A comparison of production performance between caged and free-range HyLine Brown layers, Poult. Sci., 88, 21-25, 2009.

Batkowska, J., Brodacki, A., and Knaga, S.: Quality of laying hen eggs during storage depending on egg weight and type of cage system (conventional vs. furnished cages), Ann. Anim. Sci., 14, 707-719, 2014.

Đukić-Stojčić, M., Perić, L., Bjedov, S., and Milošević, N.: The quality of table eggs produced in different housing systems, Biotechnol. Anim. Husb., 25, 1103-1108, 2009.

Đukić-Stojčić, M., Perić, L., Milošević, N., Rodić, V., Glamočić, D., Škrbić, Z., and Lukić, M.: Effect of genotype and housing system on egg production, egg quality and welfare of laying hens, J. Food Agric. Environ., 10, 556-559, 2012.

Englmaierová, M., Tůmová, E., Charvátová, V., and Skřivan, M.: Effects of laying hens housing system on laying performance, 
egg quality characteristics, and egg microbial contamination, Czech J. Anim. Sci., 59, 345-352, 2014.

Ferrante, V., Lolli, S., Vezzoli, G., and Cavalchini, L. G.: Effects of two different rearing systems (organic and barn) on production performance, animal welfare traits and egg quality characteristics in laying hens, Ital. J. Anim. Sci., 8, 165-174, 2009.

Gerzilov, V., Datkova, V., Mihaylova, S., and Bozakova, N.: Effect of poultry housing systems on egg production, Bulg. J. Agric. Sci., 18, 955-956, 2012.

Golden, J. B., Arbona, D. V., and Anderson, K. E.: A comparative examination of rearing parameters and layer production performance for brown egg-type pullets grown for either free-range or cage production, J. Appl. Poult. Res., 21, 95-102, 2012.

IBM: Corp. Released, IBM SPSS Statistics for Windows, Version 20.0, IBM Corp., Armonk, NY, 2011.

Krawczyk, J.: Quality of eggs from Polish native Greenleg Partridge chicken-hens maintained in organic vs. backyard production systems, Anim. Sci. Pap. Rep., 27, 227-235, 2009.

Krawczyk, J. and Sokołowicz, Z.: Effect of chicken breed and storage conditions of eggs on their quality, Acta Sci. Pol.-Zootech., 14, 109-118, 2015.

Krawczyk, J., Sokołowicz, Z., and Szymczyk, B.: Effect of housing system on cholesterol, vitamin and fatty acid content of yolk and physical characteristics of eggs from Polish native hens, Arch. Geflugelkd., 75, 151-157, 2011.

Küçükyılmaz, K., Bozkurt, M., Herken, E.N., Çınar, M., Çatlı, A.U., Bintaş, E. and Çöven, F.: Effects of rearing systems on performance, egg characteristics and immune response in two layer hen genotype, Asian Australas, J. Anim. Sci., 25, 559-568, 2012.

Lewko, L. and Gornowicz, E.: Effect of housing system on egg quality in laying hens, Ann. Anim. Sci., 11, 607-616, 2011.

Luiting, P.: Genetic variation of energy partitioning in laying hens: Causes of variation in residual feed consumption, World's Poult. Sci. J., 46, 132-152, 1990.

Lukanov, H. and Alexieva, D.: Trends in battery cage husbandry systems for laying hens. Enriched cages for housing laying hens, J. Agr. Sci. Tech., 5, 143-152, 2013.

Miao, Z. H., Glatz, P. C., and Ru, Y. J.: Free-range poultry production - A review, Asian Australas, J. Anim. Sci., 18, 113-132, 2005.

Mohammed, K. A. F., Sarmiento-Franco, L., Santos-Ricalde, R., and Solorio-Sanchez, J. F.: Egg production, egg quality and crop content of Rhode Island Red hens grazing on natural tropical vegetation, Trop. Anim. Health Prod., 45, 367-372, 2013.

Özbey, O. and Esen, F.: The effects of different breeding systems on egg productivity and egg quality characteristics of rock partridges, Poult. Sci., 86, 782-785, 2007.

Pištěková, V., Hovorka, M., Večerek, V., Straková, E., and Suchý, P.: The quality comparison of eggs laid by laying hens kept in battery cages and in a deep litter system, Czech J. Anim. Sci., 51, 318-325, 2006.
Połtowicz, K., Wężyk, S., Calik, J., and Paściak, P.: The use of native chickens breed in poultry meat production, in: Proceedings of the British Society of Animal Science, 14-15 October 2004, Cracow, 30-32, 2004.

Rizzi, C. and Chiericato, G. M: Organic farming production. Effect of age on the productive yield and egg quality of hens of two commercial hybrid lines and two local breeds, Ital. J. Anim. Sci., 4, 160-162, 2005.

Roll, V. F. B., Briz, R. C., and Levrino, G. A. M.: Floor versus cage rearing: effects on production, egg quality and physical condition of laying hens housed in furnished cages, Cienc. Rural, 39, 1527$1532,2009$.

Safaa, H. M., Serrano, M. P., Valencia, D. G., Arbe, X., JiménezMoreno, E., Lázaro, R., and Mateos, G. G.: Effects of the levels of methionine, linoleic acid, and added fat in the diet on productive performance and egg quality of brown laying hens in the late phase of production, Poul. Sci., 87, 1595-1602, 2008.

Sarica, M., Onder, H., and Yamak, U. S.: Determining the most effective variables for egg quality traits of five different hen genotypes, Int. J. Agric. Biol. Eng., 14, 235-240, 2012.

Şekeroğlu, A., Sarica, M., Demir, E., Ulutaş, Z., Tilki, M., and Saatc1, M.: The effects of housing system and storage length on the quality of eggs produced by two lines of laying hens, Arch. Geflugelkd., 72, 106-109, 2008.

Şekeroğlu, A., Sarica, M., Demir, E., Ulutaş, Z., Tilki, M., Saatcı, M. and Omed, H.: Effects of different housing systems on some performance traits and egg qualities of laying hens, J. Anim. Vet. Adv., 9, 1739-1744, 2010.

Singh, R., Cheng, K. M., and Silversides, F. G.: Production performance and egg quality of four strains of laying hens kept in conventional cages and floor pens, Poult. Sci., 88, 256-264, 2009.

Tauson, R., Wahlström, A., and Abrahamsson, P.: Effect of two floor housing systems and cages on health, production, and fear response in layers, J. Appl. Poult. Res., 8, 152-159, 1999.

Tůmová, E., Skřivan, M., Englmaierová, M. and Zita, L.: The effect of genotype, housing system and egg collection time on egg quality in egg type hens, Czech J. Anim. Sci., 54, 17-23, 2009.

van den Brand, H., Parmentier, H. K., and Kemp, B.: Effects of housing system (outdoor vs cages) and age of laying hens on egg characteristics, Brit. Poult. Sci., 45, 745-752, 2004.

Wójcik, E., Andraszek, K., Gryzińska, M., Witkowski, A., Pałyszka, M., and Smalec, E.: Sister chromatid exchange in Greenleg Partridge and Polbar hens covered by the gene-pool protection program for farm animals in Poland, Poult. Sci., 91, 2424-2430, 2012.

Zita, L., Tůmová, E., and Štolc, L.: Effects of genotype, age and their interaction on egg quality in brown-egg laying hens, Acta Vet. Brno, 78, 85-91, 2009. 